\title{
BIOCOLLOIDS OF URINE IN HEALTH AND IN CALCULOUS DISEASE. II. ELECTROPHORETIC AND BIOCHEMICAL STUDIES OF A MUCOPROTEIN INSOLUBLE IN MOLAR SODIUM CHLORIDE ${ }^{1}$
}

\author{
By WILLIAM H. BOYCE AND MARJORIE SWANSON
}

(From the Department of Urology, Division of Surgery, and Department of Biochemistry, The Bowman Gray School of Medicine of Wake Forest College, Winston-Salem, N. C.)

(Submitted for publication February 23, 1955; accepted June 22, 1955)

A method for recovering the total biocolloids of urine by a combination of dialysis and ultrafiltration has been described (1). These biocolloids have been separated into two groups on the basis of their solubility in molar sodium chloride. The electrophoretic properties of those components which are soluble in molar sodium chloride have been reported, both for normal subjects and for patients with developing renal calculi (2). The urinary biocolloids which are insoluble in molar sodium chloride form the subject for the present study.

A virus inhibitory urinary mucoprotein which is insoluble in sodium chloride solutions of 0.58 $\mathrm{M}$, and only partially soluble in sodium chloride solutions as low as $0.14 \mathrm{M}$ was first discovered by Tamm and Horsfall in 1950 (3). In 1952, further reports by Tamm and Horsfall (4), Gottschalk (5), and Odin (6) indicated that this mucoprotein was a potent inhibitor of hemagglutination by influenza viruses. The physical homogeneity, molecular weight, and axial ratio of this substance have been delineated by Tamm, Perlmann, Horsfall, Bugher, and Porter, employing electrophoretic (7), ultracentrifugal (8), and electronmicroscopic (9) methods. Burnet (10) has reported alterations in the capacity of this mucoprotein to inhibit viral hemagglutination following periodate treatment, and loss of its ability to produce agglutination of erythrocytes following treatment with $5 \mathrm{M}$ urea solution. Curtain (11) found that the solubility of this mucoprotein in solutions of sodium chloride was much increased by treatment with $6.5 \mathrm{M}$ urea solution. $\mathrm{He}$ observed that the presence of calcium, ionic strength

1 This investigation was supported by research grant A-259 (C2) from the National Institute of Arthritis and Metabolic Diseases, of the National Institutes of Health, Public Health Service. $\mu=0.023$, and magnesium, ionic strength $\mu=$ 0.017 , prevented urea from altering the viscosity and the hemagglutinating and virus-inhibitory properties of the mucoprotein (12).

The current studies have demonstrated that ultrafiltration of dialyzed urine, followed by extraction of the retained gel with molar sodium chloride, yields a residue which in chemical composition is indistinguishable from the urinary mucoprotein of Tamm and Horsfall. In the present report the amount of $\mathrm{NaCl}$-insoluble mucoprotein in urine of normal subjects is compared with that in urine from patients with calcigerous renal calculi. The effect of solutions with a $\mathrm{pH}$ of 12.3 on the solubility of this mucoprotein, and the electrophoretic behavior of the mucoprotein after exposure to such solutions are also reported.

\section{MATERIAL AND METHODS}

Studies were performed on five to ten 24-hour specimens of urine from each of 8 normal subjects, 14 patients with calcigerous renal calculi, and 2 patients who had bilateral cutaneous ureterostomies as a result of cystectomy performed for carcinoma of the bladder. In an effort to reduce bacterial activity to a minimum, all patients received intensive therapy with antibiotic or chemotherapeutic agents, or both, before and during the period of study.

All the buffer solutions used were of 0.1 ionic strength, and were prepared according to the method described by Miller and Golder (13). Determinations of $\mathrm{pH}$ were made with the glass electrode. Conductivity studies were made in a Shedlovsky type cell at $0.5 \mathrm{C}$. Electrophoretic studies were carried out in the Aminco apparatus, in the manner previously described (2). Analyses for nitrogen, carbon, hydrogen, sulfur, and sulfate were done by a commercial analyst (14). The hexose, hexosamine, fucose, and "sialic acid" determinations were made by Dr. Richard Winzler (15), using techniques which he has described (16). The analyses for nitrogen and for hexose, hexosamine, and "sialic acid" were also done in our own laboratory. Purified samples of orosomucoid (human serum mucoprotein, MP-1) were provided by 
Dr. Winzler as a standard for the "sialic acid" determinations. It was noted that the color of the urinary mucoprotein preparations developed with the diphenylamine reaction is not identical to the color of those developed in the standards prepared from serum mucoprotein; hence the values for "sialic acid" in urinary mucoprotein may not be entirely comparable to values obtained by similar determinations performed on serum mucoproteins.

Twenty-four-hour specimens of urine were collected into sterile, refrigerated containers and were kept at temperatures of 1 to $5 \mathrm{C}$. during the entire study. Specimens with a specific gravity of more than 1.010 were diluted with distilled water, since with moderate centrifugal force the material under study sediments from concentrated urine (4). After adjustment of the specific gravity, all specimens were centrifuged to remove formed elements. The total biocolloids of each specimen were then recovered by cold dialysis and ultrafiltration, and soluble components were removed by extraction with $M$ sodium chloride in the manner previously described (2).

The dry weights of the insoluble residues contained in one to five 24-hour urine specimens from each subject were determined after dialysis in the cold against distilled water, lyophilization, and subsequent drying in vacuo for 24 hours at $20 \mathrm{C}$. The lyophilized residues were then used for elementary and carbohydrate analyses.

The remaining insoluble residues which had been frozen for storage were prepared for electrophoresis in the following manner: The residue was suspended in glycine buffer of $\mathrm{pH} 12.3$, and dialyzed against the same buffer for 24 hours at $1 \mathrm{C}$., with frequent gentle agitation. Any insoluble residue was removed by centrifugation, and portions of the clear supernatant fluid were equili-

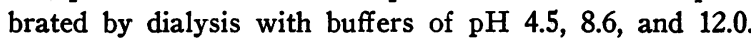
The times and potential gradients used were as follows:

At $\mathrm{pH} 4.5-10,800 \mathrm{sec}$., 6 volts per $\mathrm{cm}$.

At $\mathrm{pH} 8.6-7,200 \mathrm{sec}$., 7.4 volts per $\mathrm{cm}$.

At $\mathrm{pH} 12.0-7,200 \mathrm{sec} ., 6$ volts per $\mathrm{cm}$.

All studies were made at $0.5 \mathrm{C}$. and in accordance with techniques previously described (2). After electrophoresis, the degraded mucoprotein was recovered by dialysis against distilled water, followed by lyophilization. This residue was submitted to elementary and carbohydrate analyses.

Both normal serum proteins and purified serum mucoprotein (MP-1), to which Winzler has recently given the name orosomucoid (16), were used to obtain comparative electrophoretic patterns.

\section{RESULTS}

\section{Dry weights of the residues insoluble in molar so- dium chloride}

The weights of the residues from normal individuals were strikingly constant, ranging from 38 to $56 \mathrm{mg}$. in 18 determinations performed on 24hour urine specimens. The average yield from 3 normal subjects studied for five consecutive days was $44 \mathrm{mg}$. per day. The 24 -hour residues from the urine of patients with calculous disease demonstrated a marked quantitative variation, not only between individuals but from day to day for the same individual. The dry weights of these residues ranged from 147 to $1,040 \mathrm{mg}$. per 24 hours. For the two patients who had cutaneous ureterostomies, the dry weights of the residues insoluble in molar sodium chloride were, respectively, 18 and $12 \mathrm{mg}$. per 24 hours.

\section{Chemical composition of the residues insoluble in molar sodium chloride}

The results of chemical analyses of the $\mathrm{NaCl}$ insoluble mucoprotein recovered in our laboratory and other laboratories are given in Tables I and II. All analyses were performed on material which was first dialyzed against distilled water and recovered by lyophilization, then dried in vacuo at room temperature to a constant weight. These results indicate the similarity between the virus inhibitory mucoprotein of Tamm and Horsfall and the $\mathrm{NaCl}$-insoluble portion of the residue recovered by ultrafiltration of urine.

We have been unable to demonstrate any significant qualitative difference in this material between the normal subjects and 11 of the 14 patients with calculous disease. In 3 patients who had renal calculi and persistent urinary infection with $B$. proteus the hexosamine content of the mucoprotein was decreased (Table II). No other variations in carbohydrate content were noted in the mucoprotein recovered from these patients. These were the only patients from whom this organism was cultured in the present study.

\section{Electrophoretic studies of the residues insoluble in molar sodium chloride}

In phosphate buffers of $\mathrm{pH} 6.8$ and ionic strength 0.05 , the lyophilized material was found to have a mobility of $-8.6 \times 10^{-5} \mathrm{~cm} .^{2}$ per volt sec. This figure agrees with that reported by Perlmann, Tamm, and Horsfall (7), who also used the phosphate-soluble portion of lyophilized mucoprotein. 
TABLE I

Inorganic analysis of urinary mucoprotein as reported by different investigators (expressed as per cent of dry weight)

\begin{tabular}{|c|c|c|c|c|c|c|c|c|}
\hline \multirow[b]{2}{*}{ Author } & \multirow[b]{2}{*}{ Nitrogen } & \multirow[b]{2}{*}{ Carbon } & \multirow[b]{2}{*}{ Hydrogen } & \multicolumn{3}{|c|}{ Sulfur } & \multirow{2}{*}{$\begin{array}{l}\text { Phos- } \\
\text { phorus }\end{array}$} & \multirow{2}{*}{$\begin{array}{l}\text { Acetyl } \\
\text { groups }\end{array}$} \\
\hline & & & & Sulfate & Other & Total & & \\
\hline $\begin{array}{l}\text { Tamm and Horsfall (4) } \\
\text { Preparation } 1\end{array}$ & 12.2 & 48.8 & 6.65 & & & \multirow{2}{*}{$\begin{array}{c}3.09 \\
\text { (Parr Bomb) } \\
1.82 \\
\text { (Carius) }\end{array}$} & \multirow{2}{*}{$\begin{array}{l}\text { None } \\
\text { None }\end{array}$} & \\
\hline Preparation 2 & 11.8 & 46.4 & 6.84 & & & & & \\
\hline $\begin{array}{l}\text { Odin }(6) \\
\text { Preparation } 1 \\
\text { Preparation } 2 \\
\text { Preparation } 3\end{array}$ & $\begin{array}{l}11.2 \\
10.9 \\
10.7\end{array}$ & & & & & $\begin{array}{l}0.4 \\
0.8\end{array}$ & $\begin{array}{l}0.09 \\
0.16\end{array}$ & \\
\hline \multicolumn{7}{|l|}{ Normal Subjects } & & \\
\hline $\begin{array}{l}\text { As recovered } \\
\text { After treatment at }\end{array}$ & 12.2 & 48.9 & 6.9 & 1.43 & 0.37 & 1.80 & None & 0.27 \\
\hline $\mathrm{pH} 12.3$ & 10.3 & 49.2 & 6.9 & 1.19 & 0.40 & 1.59 & None & 1.35 \\
\hline \multirow{2}{*}{$\begin{array}{l}\text { Calculous disease } \\
\text { (Av. for } 11 \text { patients*) } \\
\text { As recovered } \\
\text { After treatment at } \\
\text { pH } 12.3\end{array}$} & 12.9 & 49.4 & 7.0 & 1.21 & 0.38 & 1.59 & None & 0.28 \\
\hline & 11.3 & 50.9 & 7.0 & 1.26 & 0.38 & 1.64 & None & 1.20 \\
\hline
\end{tabular}

* Not including 3 patients with persistent urinary infection with $B$. proteus.

When the $\mathrm{NaCl}$-insoluble residue was suspended in veronal buffer of $\mathrm{pH} 8.6$ immediately after recovery from the ultrafilter and prior to freezing or other treatment, it was found to migrate toward the anode with a mobility of $-8.3 \times 10^{-5} \mathrm{~cm} .^{2}$ per volt sec. Whether this unfrozen material can be considered "soluble" in this buffer is debatable, since it can be sedimented by centrifugation at $500 \times g$ for 60 minutes.

Figure 1 illustrates by electrophoretic patterns the presence of this mucoprotein in the entire protein residue recovered by ultrafiltration of uri-

TABLE II

Carbohydrate content of urinary mucoprotein as reported by different investigators (expressed as per cent of dry weight)

\begin{tabular}{|c|c|c|c|c|c|c|c|c|}
\hline \multirow[b]{2}{*}{ Author } & \multicolumn{3}{|c|}{ Hexose } & \multirow[b]{2}{*}{ Hexosamine } & \multirow[b]{2}{*}{ Fucose } & \multicolumn{2}{|c|}{ "Sialic acid" } & \multirow[b]{2}{*}{ Total } \\
\hline & Galactose & Mannose & Total & & & Ehrlich & Bial & \\
\hline Gottschalk (5) & 5.4 & 2.7 & 8.1 & 7.6 & 1.0 & & & \\
\hline $\begin{array}{l}\text { Odin }(6) \\
\text { Preparation } 1 \\
\text { Preparation } 2 \\
\text { Preparation } 3 \\
\text { Average }\end{array}$ & & & $\begin{array}{l}6.8 \\
8.4 \\
9.0 \\
8.3\end{array}$ & $\begin{array}{l}6.4 \\
9.4 \\
7.0 \\
7.7\end{array}$ & $\begin{array}{l}0.7 \\
1.1 \\
1.1 \\
1.0\end{array}$ & $\begin{array}{l}8.2 \\
9.2 \\
9.4 \\
8.9\end{array}$ & $\begin{array}{l}7.3 \\
9.1 \\
9.1 \\
8.5\end{array}$ & $\begin{array}{l}22.1 \\
28.1 \\
26.5 \\
25.9\end{array}$ \\
\hline $\begin{array}{l}\text { Present study } \\
\text { Normal subjects }\end{array}$ & & & & & & & & \\
\hline $\begin{array}{l}\text { As recovered } \\
\text { After treatment at } \\
\quad \text { pH } 12.3\end{array}$ & & & $\begin{array}{l}8.4 \\
8.3\end{array}$ & $\begin{array}{l}7.1 \\
2.3\end{array}$ & $\begin{array}{l}1.1 \\
1.2\end{array}$ & $\begin{array}{l}9.1 \\
8.8\end{array}$ & & $\begin{array}{l}25.7 \\
20.6\end{array}$ \\
\hline $\begin{array}{l}\text { Calculous disease } \\
\text { (Av. for } 11 \text { patients*) } \\
\text { As recovered } \\
\text { After treatment at } \\
\text { pH } 12.3\end{array}$ & & $\therefore$ & $\begin{array}{l}8.1 \\
8.0\end{array}$ & $\begin{array}{l}7.4 \\
2.5\end{array}$ & $\begin{array}{l}1.0 \\
0.8\end{array}$ & $\begin{array}{l}9.0 \\
8.8\end{array}$ & & $\begin{array}{l}25.5 \\
20.1\end{array}$ \\
\hline
\end{tabular}

* Not including 3 patients with $B$. proteus infection whose mucoproteins gave hexosamine contents of $2.5,2.5$, and 4.8 per cent without significant variation in other carbohydrate components. 


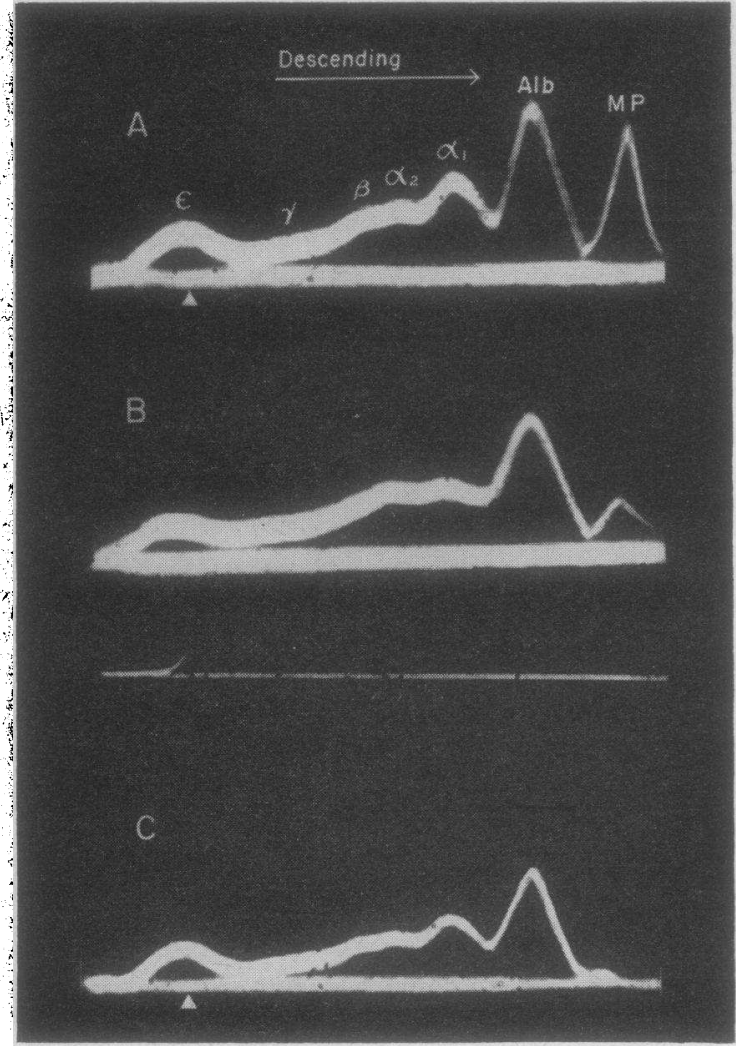

Fig. 1. Electrophoretic Migration Patterns of Urinary Proteins from a Patient with PyelonePHRITIS (B. Coli)

Slit diaphragm, cylindrical lens patterns of boundaries descending toward the anode. Veronal buffer, $\mathrm{pH} 8.6$, ionic strength 0.1 , potential gradient 6.6 volts per $\mathrm{cm}$., time, 7,200 sec.

A. Entire gel recovered from ultrafiltration of urine was suspended in buffer without freezing or centrifugation and electrophoresis performed after equilibration dialysis against buffer. MP-Tamm and Horsfall mucoprotein, Alb.-Albumin, $\epsilon$-salt boundary. The MP boundary has been retouched to facilitate copying.

B. Entire gel recovered from ultrafiltration of urine treated as $A$ with the exception of centrifugation at $500 \times g$ for $1 \mathrm{hr}$. just prior to electrophoresis. The sediment was identified as $\mathrm{T} \& \mathrm{H}$ mucoprotein by electrophoresis after treatment at $\mathrm{pH}$ 12.3.

C. Entire gel recovered from ultrafiltration of urine treated as $\mathrm{A}$ with the exception that $\mathrm{NaCl}$ was added to make the whole $0.58 \mathrm{M}$ with respect to $\mathrm{NaCl}$, centrifuged at $500 \times g$ for $1 \mathrm{hr}$., and electrophoresis performed after equilibration dialysis against buffer. Sediment identified as $T \& H$ mucoprotein by nitrogen and carbohydrate content.

nary proteins from a patient with pyelonephritis. The entire gel recovered from the ultrafilters was suspended in veronal buffer of $\mathrm{pH} 8.6$ immediately after recovery, and this solution was then divided into three equal parts. Portion " $A$ " was subjected to electrophoresis without further treatment other than dialysis against the buffer for 24 hours (Figure 1-A). A large component was observed to migrate with a mobility of $-7.44 \times 10^{-5} \mathrm{~cm}^{2}$ per volt sec. This figure is 25 per cent greater than the mobility of the albumin fraction, and is exactly the same as the mobility of the fast component "fc-1" (2). Part " $B$ " was dialyzed against the buffer for 24 hours and centrifuged at $500 \times g$ for 60 minutes prior to electrophoresis. The loss of this large component (MP in Figure 1) by sedimentation during centrifugation is illustrated in Figure 1-B. Sodium chloride was added to portion " $C$ " to make a $0.58 \mathrm{M}$ solution with respect to sodium chloride. This was then centrifuged for one hour at $500 \times g$, dialyzed against veronal buffer for 48 hours, and subjected to electrophoresis. The loss of the component with a mobility greater than albumin is illustrated in Figure 1-C.

\section{Solubility of the residues insoluble in molar so- dium chloride}

Freezing of the residue remaining after extraction with molar sodium chloride was found to exert a profound effect on its solubility. When this material was recovered from a pool formed by freezing successive 24-hour samples of urinary biocolloids, the residue was highly insoluble in veronal buffer of $\mathrm{pH} 8.6$ (2). However, it was possible to obtain suspensions of 1 to 2 per cent of the frozen mucoprotein in this buffer, and these appeared stable enough for an attempt at electrophoretic studies. At $0.5 \mathrm{C}$. these suspensions formed thixotropic gels within the electrophoresis cells, and the bulk of the material either precipitated spontaneously or remained immobile in the position of the "salt" boundaries. A barely detectable quantity was usually observed to migrate, with a mobility of approximately $-8 \times 10^{-5} \mathrm{~cm}^{2}$ per volt sec. This gelation occurred whether the residues were obtained from normal urine or from patients with calculous disease, and whether the material was recovered by precipitation with $0.58 \mathrm{M}$ sodium chloride or by ultrafiltration.

It was considered that the solubility of the mucoprotein might be affected by the presence of al- 
kaline earth metals bound from the urine, either prior to precipitation with sodium chloride or by filtration of dialyzed urine through the gel as it formed on the collodion membrane. In an effort to remove all the alkaline earth metals, the $\mathrm{NaCl}$ insoluble residue was suspended in distilled water and dialyzed for 72 hours against three changes of a solution prepared by dissolving $5 \mathrm{gm}$. of tetrasodium ethylenediaminetetra-acetate in 1 liter of acetate buffer of $\mathrm{pH} 4.5$. The final $\mathrm{pH}$ of this solution was 7.4. Samples of both dialyzed and undialyzed material were filtered after being treated at $100 \mathrm{C}$. in 10 per cent nitric acid. The filtrate was concentrated and examined spectroscopically (17). Although no magnesium was detected in either sample, both contained calcium; there appeared to be less calcium, however, in the samples treated with ethylenediaminetetraacetate. After dialysis against EDTA the mucoprotein appeared to be more easily suspended in buffers of ionic strength 0.1 , but centrifugation at $500 \times g$ for 60 minutes resulted in sedimentation of the suspended material.

\section{Modification of the residues insoluble in molar sodium chloride by treatment at $p H 12.3$}

When the $\mathrm{NaCl}$-insoluble mucoprotein was suspended in buffers of $\mathrm{pH} 12.3$ at 1 to $5 \mathrm{C}$., it became progressively converted to a highly soluble form. Within the first 24 hours approximately one-half became soluble, and after 72 hours only a small gum-like residue remained, amounting to approximately 6 per cent by weight of the original material. Treatment of the mucoprotein at $\mathrm{pH}$ 12.3 for ten days did not appear to result in further alteration of its properties. This highly soluble form appeared to be a degradation product of the original material, having lost two-thirds of the hexosamine content (Tables I and II). This soluble product was electrophoretically homogeneous and retained a net negative charge throughout the $\mathrm{pH}$ range of 4.5 to 12 . It was possible to reproduce this material from the $\mathrm{NaCl}$ insoluble residue of every subject in the present series, even when it had been previously lyophilized or frozen.

In Figure 2 the electrophoretic patterns of normal human serum are compared with those of the degraded urinary mucoprotein at $\mathrm{pH}$ 4.5. The

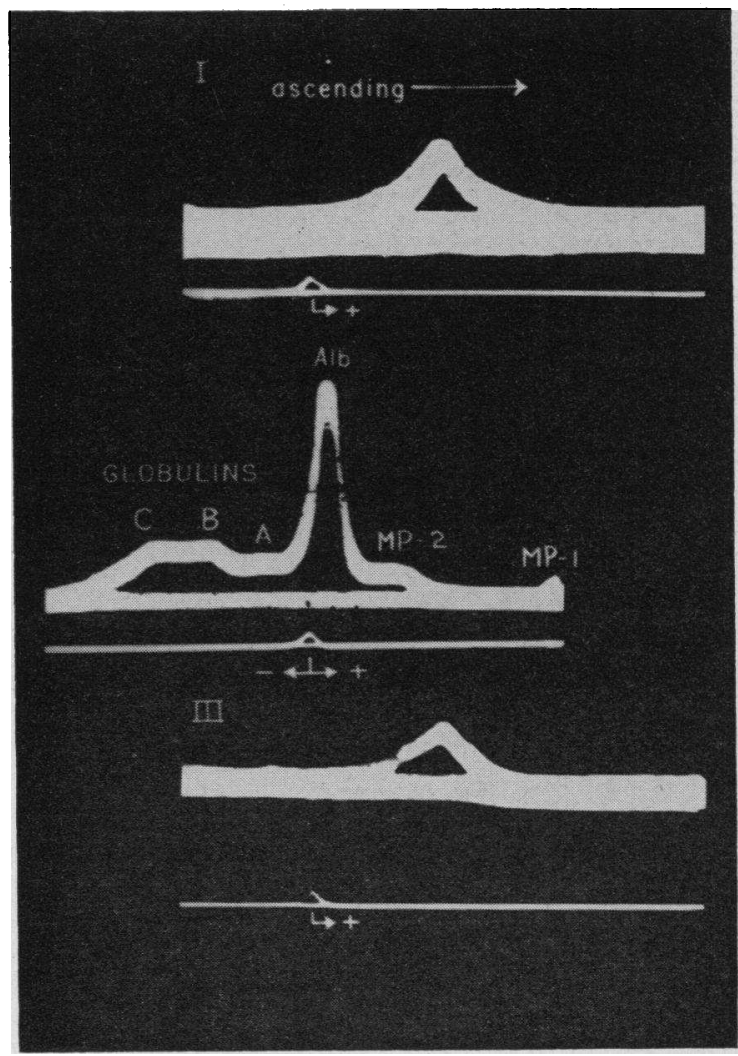

Fig. 2. Comparative Electrophoretic Patterns at PH 4.5 of Urinary Mucoprotein Treated at PH 12.3 and Normal Human Serum Proteins

I. Treated Urinary Mucoprotein from Normal SubJECT

II. Human Serum Proteins from Normal Subject

III. Treated Urinary Mucoprotein from Patient with Renal Calculi

Slit diaphragm, cylindrical lens patterns of boundaries ascending toward the anode. Acetate buffer, $\mathrm{pH} 4.5$, ionic strength 0.1 , potential gradient 6.0 volts per $\mathrm{cm}$., time $10,800 \mathrm{sec}$.

degraded mucoprotein retains a net negative charge and migrates toward the anode with a mobility greater than that of the glycoprotein, MP-2, and much less than that of the orosomucoid, MP-1, of the serum.

Figure 3 is a series of Schlieren diagrams obtained from a mixture of degraded urinary mucoprotein and orosomucoid at $\mathrm{pH}$ 4.5. Under these conditions the urinary mucoprotein had a mobility of $-2.09 \times 10^{-5} \mathrm{~cm} .^{2}$ per volt sec., as compared with $-3.96 \times 10^{-5} \mathrm{~cm}^{2}$ per volt sec. for this preparation of serum orosomucoid.

Figure 4 is a comparison of the electrophoretic 


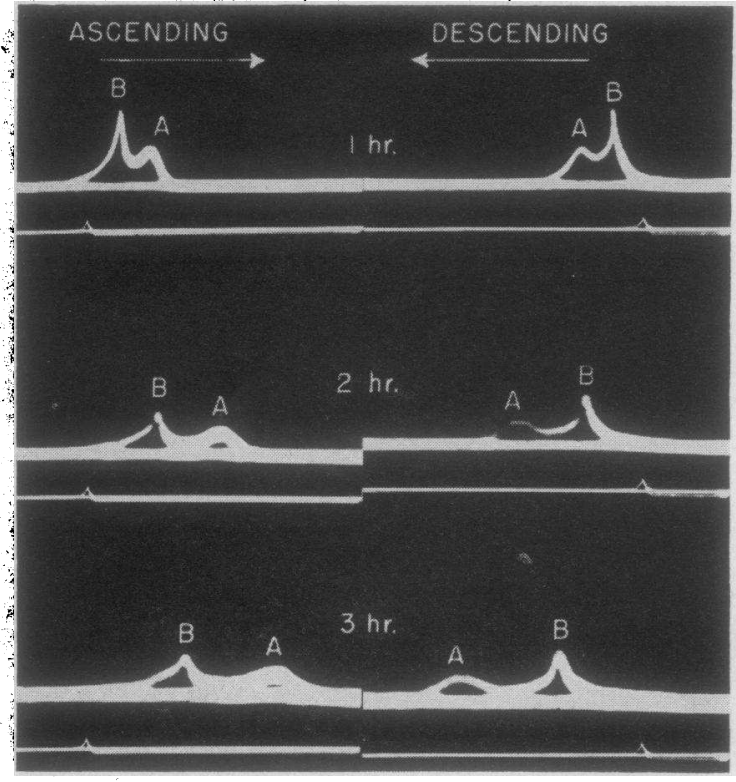

Fig. 3. Comparative Electrophoretic Patterns at PH 4.5 of Urinary Mucoprotein Treated at pH 12.3 and Normal Human Serum Orosomucoid (MP-1)

Acetate buffer, $\mathrm{pH} 4.5$, ionic strength 0.1 , potential gradient 6.2 volts per $\mathrm{cm}$. A. Orosomucoid (serum mucoprotein MP-1). B. Treated urinary mucoprotein from normal subject.

patterns of the degraded urinary mucoprotein and normal human serum at $\mathrm{pH}$ 8.6. The urinary mucoprotein has a mobility of $-5.56 \times 10^{-5} \mathrm{~cm}^{2}$ per volt sec., as compared with $-5.94 \times 10^{-5}$ cm. ${ }^{2}$ per volt sec. for albumin and $-5.07 \times 10^{-5}$ cm. ${ }^{2}$ per volt sec. for the alpha-1 globulin under similar conditions.

In Figure 5 the electrophoretic patterns of degraded urinary mucoprotein and normal serum are compared at $\mathrm{pH} 12.0$. The urinary mucoprotein has a mobility less than that of any of the components of normal serum, which are poorly separated under these conditions.

\section{DISCUSSION}

Approximately half of the total biocolloids recovered from normal urine by ultrafiltration are insoluble in molar sodium chloride. The extraction of this residue in a variety of buffers ranging from $\mathrm{pH} 4.5$ to 12.0 and with ionic strengths of $0.025,0.05$ and 0.1 have failed to produce evidence that this residue contains more than one mucoprotein. The results of the current studies indicate that this residue is the same material as the virus inhibitory mucoprotein of Tamm and Horsfall (4).

The previously reported techniques for recovery of virus inhibitory mucoprotein from the $\mathrm{NaCl}$-insoluble precipitate of urine included a step in which an insoluble residue was discarded (4, 18). Hence it was thought that the mucoprotein of Tamm and Horsfall was more soluble than that which forms the subject of the present study, and we suggested that the $\mathrm{NaCl}$-insoluble mucoprotein recovered from urine by ultrafiltration should be designated uromucoid (19). The present studies and other recent publications $(8,9)$, however, in-

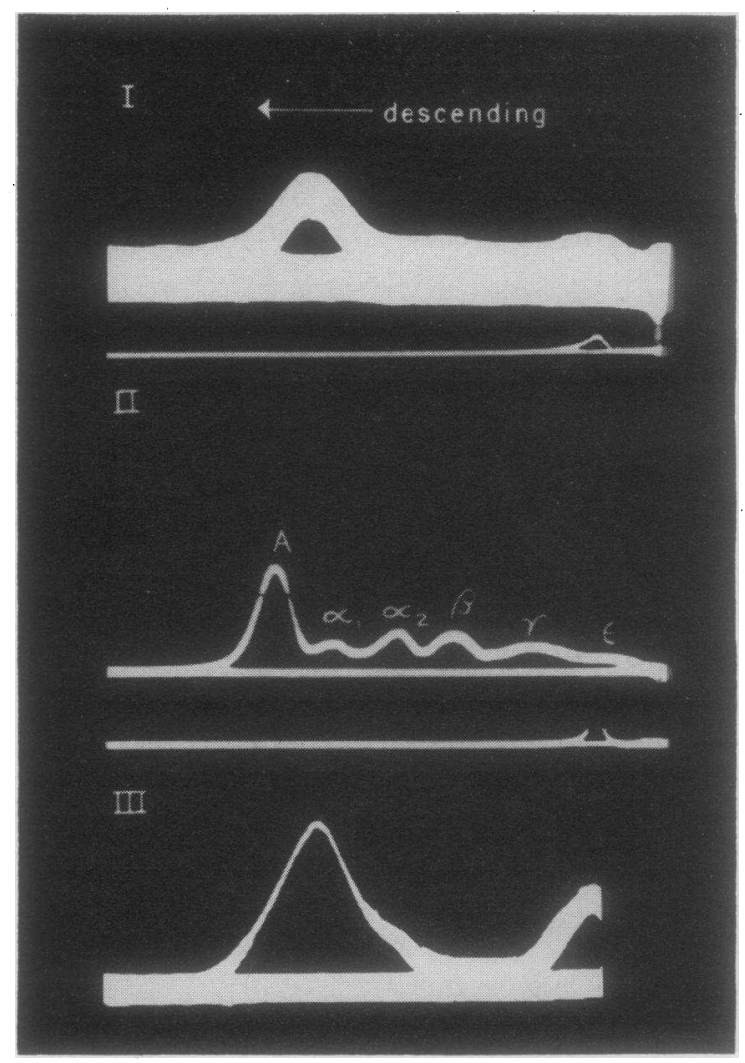

Fig. 4. Comparative Electrophoretic Patterns at pH 8.6 of Urinary Mucoproteins Treated at pH 12.3 and Normal Human Serum Proteins

\section{Treated Urinary Mucoprotein from Normal Sub-} JECT

II. Normal Human Serum Proteins

III. Treated Urinary Mucoprotein from Patient with Renal Calculi

Slit diaphragm, cylindrical lens patterns of boundaries descending toward the anode. Veronal buffer, pH 8.6, ionic strength 0.1 , potential gradient 7.4 volts per $\mathrm{cm}$., time $7,200 \mathrm{sec}$. 


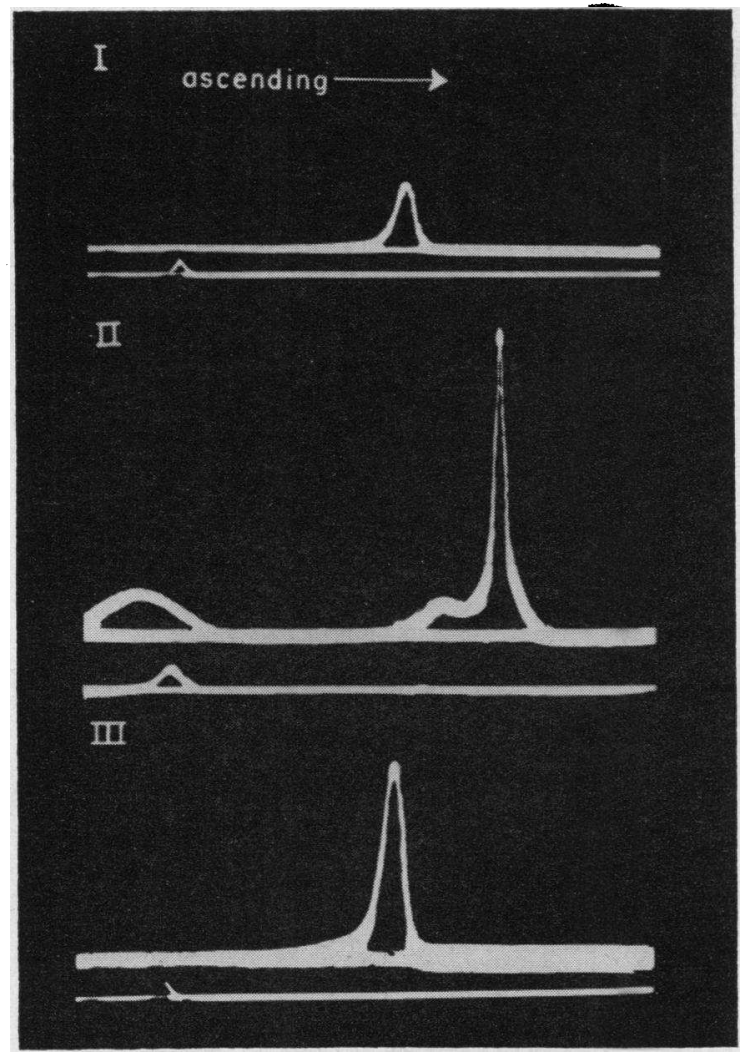

Fig. 5. Comparative Electrophoretic Patterns at pH 12.0 of Urinary Mucoproteins Treated at PH 12.3 and Normal Human Serum Proteins

I. Treated Urinary Mucoprotein from Normal SubJECT

II. Normal Human Serum Proteins

III. Treated Urinary Mucoprotein from Patient with Renal Calculi

Slit diaphragm, cylindrical lens patterns of boundaries ascending toward the anode. Glycine buffer, $\mathrm{pH} 12.0$, ionic strength 0.1 , potential gradient 6.0 volts per $\mathrm{cm}$., time 7,200 sec.

dicate that uromucoid and the virus inhibitory mucoprotein of Tamm and Horsfall are probably one and the same. In recognition of the original investigations of these workers it is suggested that this material should be referred to as "T\&H mucoprotein."

$\mathrm{T} \& \mathrm{H}$ mucoprotein is present in normal urine in remarkably constant quantities, averaging 46 mg. per 24 hours. The ratio of $\mathrm{NaCl}$-insoluble residue to $\mathrm{NaCl}$-soluble proteins in normal urine is thus $1: 1$ (2). In patients with renal calculous disease a marked increase in the urinary content of $\mathrm{T} \& \mathrm{H}$ mucoprotein, with considerable day-to-day variation, was demonstrated. In the present series of 14 such patients the ratio of $\mathrm{NaCl}$-insoluble to $\mathrm{NaCl}$-soluble proteins varied from 2.5 to 14 . The 2 patients with bilateral cutaneous ureterostomies were found to have only 18 and $12 \mathrm{mg}$., respectively, of $\mathrm{T} \& \mathrm{H}$ mucoprotein per 24 hours of urinary excretion. Both had had pyelonephritis and had an average total urinary protein excretion per 24 hours of 460 and $1200 \mathrm{mg}$., respectively. This finding is in accord with the theory (19) that this $\mathrm{NaCl}$-insoluble material may be a product secreted by the transitional epithelium of the urinary tract. The small quantity present in the urine of these patients is attributed to secretions from the ureters, renal pelves, and possibly the collecting tubules.

The chemical composition of T\&H mucoprotein recovered from most of the patients with calculous disease was essentially the same as that recovered from normal individuals. These studies do not afford unequivocal evidence that the mucoprotein is exactly the same material in these two groups of subjects. Tamm has suggested a molecular weight of $7,000,000$ for the normal mucoprotein, and considerable alteration in the composition or structure of such a large molecule could easily escape detection by the above methods of analysis.

The alteration in the "solubility" of this mucoprotein by such simple measures as freezing demonstrates the wisdom of Tamm's emphasis on the necessity for technical care in isolating mucoproteins in their native state (8). This effect of freezing is believed to account for the small quantity of $\mathrm{fc}-1$ previously observed in our own experiments (2), and for the small quantity of the "X" fraction observed by Rigas and Heller (20). The electrophoretic mobility of unfrozen $\mathrm{T} \& \mathrm{H}$ mucoprotein, in the presence of other urinary proteins at $\mathrm{pH} 8.6$, was found to be $-7.4 \times 10^{-5} \mathrm{~cm}^{2}$ per volt sec., which is exactly the same at that of fc -1 . When $\mathrm{T} \& \mathrm{H}$ mucoprotein was isolated from other urinary proteins, its mobility was increased. Even in the protein mixture the mobility of this material in the ascending limb of the cell was found to be as much as $-8 \times 10^{-5} \mathrm{~cm} .^{2}$ per volt sec. in some preparations.

The tendency of $\mathrm{T} \& \mathrm{H}$ mucoprotein to thixotropy is apparently accentuated when the material has been frozen or exposed to temperatures near 
$0 \mathrm{C}$. The observation that this material may form a thixotropic gel during the period of thermal equilibration of the electrophoresis cell suggests that the preparatory conditions existing in experiments previously reported $(2,20)$ may have caused this mucoprotein to appear at two positions in the electrophoretic pattern. The large delta and epsilon boundaries which Rigas and Heller designated "salt plus polysaccharide" may be due in part to immobilization of the T\&H mucoprotein as a result of gelation. The fast components (designated $\mathrm{fc}-1$ in our previous publication and the " $\mathrm{X}$ " component by Rigas and Heller) are considered to represent the small "soluble" quantity of $\mathrm{T} \& \mathrm{H}$ mucoprotein which escaped entrapment in the gel.

Tamm, Bugher, and Horsfall has observed that incubation of the mucoprotein at $70 \mathrm{C}$. resulted in conversion of the original molecule to a more soluble form, which was homogeneous and of reduced sedimentation in the ultracentrifuge (8). Curtain found that treatment with increasing concentrations of urea progressively diminished the axial ratio of this mucoprotein, and that in urea concentrations above $6.5 \mathrm{M}$ the virus-inhibitory titer was also reduced. His urea-treated preparations were much more soluble than the untreated material (11). The present studies have demonstrated that treatment of the mucoprotein at $\mathrm{pH} 12.3$ results in a highly soluble preparation which, to judge from the electrophoretic properties, can be repeatedly duplicated. Whether these three methods for increasing the solubility of the mucoprotein result in disrupting the same bond or bonds remains unknown.

In any event, the interpretation of electrophoretic or chromatographic $(21,22)$ diagrams of urinary proteins obtained by various methods of recovery (23) should take into account the possible presence of these various degradation products of $\mathrm{T} \& \mathrm{H}$ mucoprotein. The Astrop fraction of urine (24) and the metachromatic urinary "heparin" (25), prepared by methods which involve heating with ammonia, are certain to contain variable quantities of this mucoprotein or its alkaline degradation products, unless the $\mathrm{NaCl}$ insoluble residue is removed prior to heating and treatment at $\mathrm{pH} 12$ or more.

The previously reported affinity of this mucoprotein for calcium (19) has been emphasized by unsuccessful attempts to free calcium from the material with ethylenediaminetetraacetic acid. The possible relationship of this calcium binding activity to the formation of urinary calculi has been discussed (26).

\section{SUM MARY}

The $\mathrm{NaCl}$-insoluble residue obtained from the ultrafiltration of urine appears to be a single mucoprotein which is indistinguishable from the virus-inhibitory mucoprotein of Tamm and Horsfall. The quantity of this material is much increased in the urine of patients with renal calculous disease. In the absence of active bacterial infection of the urinary tract, the mucoprotein recovered from such patients was qualitatively similar to that recovered from normal subjects. The methods of analysis, however, are admittedly not sensitive enough to detect alterations in structure or even moderate alterations in composition of the exceedingly large molecules under consideration.

The physical properties of the mucoprotein are altered by such simple laboratory procedures as freezing. This fact emphasizes the meticulous care required to recover this mucoprotein in its native state.

Treatment of this mucoprotein at $\mathrm{pH} 12.3$ results in the formation of a highly soluble degradation product which is consistently recovered even from material that has been denatured by freezing or lyophilization. Recognition of the presence of this degradation product may be of value in studies of the mucoprotein under conditions where denaturization may be unavoidable.

It is suggested that the " $X$ " component of urinary proteins previously observed by Rigas and Heller (20) and the "fc -1 " component observed in this laboratory probably represented a small portion of the total Tamm and Horsfall mucoprotein which remained in suspension. It seems likely that the preparatory procedures, which involved freezing of the urinary proteins prior to electrophoresis, would cause most of this mucoprotein to be insoluble in buffers of 0.1 ionic strength.

\section{ACKNOWLEDGMENT}

The authors wish to express their appreciation to Di. Richard J. Winzler, Department of Biochemistry, Uni- 
versity of Illinois College of Medicine, Chicago, for having analyzed samples of urinary mucoprotein for carbohydrate content, and for providing the orosomucoid utilized in electrophoretic studies and as a standard for "sialic acid" determinations.

\section{REFERENCES}

1. Boyce, W. H., Garvey, F. K., and Norfleet, C. M., The turbidity of urine in the normal and in patients with urinary calculi. Exper. Med. \& Surg., 1954, 12, 450.

2. Boyce, W. H., Garvey, F. K., and Norfleet, C. M., Jr., Proteins and other biocolloids of urine in health and in calculous disease. I. Electrophoretic studies at $\mathrm{pH} 4.5$ and 8.6 of those components soluble in molar sodium chloride. J. Clin. Invest., 1954, 33, 1287.

3. Tamm, I., and Horsfall, F. L., Jr., Characterization and separation of an inhibitor of viral hemagglutination present in urine. Proc. Soc. Exper. Biol. \& Med., 1950, 74, 108.

4. Tamm, I., and Horsfall, F. L., Jr., A mucoprotein derived from human urine which reacts with influenza, mumps, and Newcastle disease viruses. J. Exper. Med., 1952, 95, 71.

5. Gottschalk, A., Carbohydrate residue of a urine mucoprotein inhibiting influenza virus haemagglutination. Nature, 1952, 170, 662.

6. Odin, L., Carbohydrate residue of a urine mucoprotein inhibiting influenza virus haemagglutination. Nature, 1952, 170, 663.

7. Perlmann, G. E., Tamm, I., and Horsfall, F. L., Jr., An electrophoretic examination of a urinary mucoprotein which reacts with various viruses. J. Exper. Med., 1952, 95, 99.

8. Tamm, I., Bugher, J. C., and Horsfall, F. L., Jr., Ultracentrifugation studies of a urinary mucoprotein which reacts with various viruses. J. Biol. Chem., 1955, 212, 125.

9. Porter, K. R., and Tamm, I., Direct visualization of a mucoprotein component of urine. J. Biol. Chem., 1955, 212, 135.

10. Burnet, F. M., Biological properties of the mucoprotein, urinary inhibitor. Australian J. Exper. Biol. \& M. Sc., 1952, 30, 251.

11. Curtain, C. C., The action of urea on the urinary inhibitor of influenza virus haemagglutination. Australian J. Exper. Biol. \& M. Sc., 1953, 31, 615.
12. Curtain, C. C., The viscometric behaviour of a mucoprotein isolated from human urine. Australian J. Exper. Biol. \& M. Sc., 1953, 31, 255.

13. Miller, G. L., and Golder, R. H., Buffers of $\mathrm{pH} 2$ to 12 for use in electrophoresis. Arch. Biochem., 1950, 29, 420.

14. Clark Microanalytical Laboratory, 1041/2 West Main Street, Urbana, Illinois.

15. Winzler, R. J., Personal communication.

16. Winzler, R. J., Determination of serum glycoproteins in Methods of Biochemical Analysis, edited by Glick, D., New York, Interscience Publishers, Inc., 1955, vol. II, p. 279-311.

17. Kress, K. E., Quantitative analysis with the spectranal; ash analysis of compounded rubber. Appl. Spectroscopy, 1952, 6, 19.

18. Ada, G. L., and Gottschalk, A., Preparation from urine of a pure substrate (mucoprotein) for the influenza virus enzyme. Australian J. Sc., 1952, 14, 160.

19. Boyce, W. H., Garvey, F. K., and Norfleet, C. M., Ion-binding properties of electrophoretically homogeneous mucoproteins of urine in normal subjects and in patients with renal calculus disease. $\mathrm{J}$. Urol., 1954, 72, 1019.

20. Rigas, D. A., and Heller, C. G., The amount of nature of urinary proteins in normal human subjects. J. Clin. Invest., 1951, 30, 853.

21. Hamerman, D., Reife, A., Bartz, K. W., and Hatch, F. T., The nature of high molecular weight carbohydrate-protein constituents in normal human urine. Report No. 154, Medical Nutrition Lab., Fitzsimons Army Hospital, U. S. Army, Denver 8, Colorado, Feb. 24, 1955.

22. Hamerman, D., Hatch, F. T., Reife, A., and Bartz, K. W., Non-dialyzable material in normal human urine. Arch. Biochem. \& Biophys., In press.

23. Anderson, A. J., and Maclagan, N. F., The isolation and estimation of urinary mucoproteins. Biochem. J., 1955, 59, 638.

24. Kerby, G. P., The excretion of glucuronic acid and of acid mucopolysaccharides in normal human urine. J. Clin. Invest., 1954, 33, 1168.

25. Jaques, L. B., Napke, E., and Levy, S. W., The metachromatic activity of urine following the injection of heparin. Circ. Research, 1953, 1, 321.

26. Boyce, W. H., Garvey, F. K., and Norfleet, C. M., Metal chelate compounds of urine, their relation to the initiation and growth of calculi. Am. J. Med., In press. 